\title{
Management of Gender-Based Production and Commercial Spaces
}

\author{
Titien Woro Murtini ${ }^{1, a)}$, Arnis Rochma Harani ${ }^{1, b)}$, Arlina Adiyati ${ }^{1, c)}$ \\ ${ }^{1}$ Departement of Architecture, Faculty of Engineering \\ Diponegoro University, Indonesia \\ a) Correspondence author: titien_wm@yahoo.com \\ b) arnis.rochma@gmail.com \\ c) arlinaadiyati@gmail.com
}

\begin{abstract}
Currently, home industry is attaining particular attention from Indonesian government. This activity is considered as an embryo of Indonesia's economic growth. One of the home industries that have been recognized worldwide is batik. Batik is the cultural heritage of Indonesia that which has received international recognition. The famous batik in Indonesia comes from Pekalongan. In Pekalongan, some villages have characteristic of batik, one of them is proto village. In this village, batik is growing through the home industry business, and almost $70 \%$ women can write batik. Also, almost all the houses in this village become a place for industry, whether to make batik, sell batik, and modify batik fabric into clothing. The house which should be a residence, it is functioned as a production and business space. This research employed qualitative method with phenomenology paradigm, aimed to understand and reveal the meaning of the phenomenon of human life behavior, both human in capacity as individuals, groups and the wider community in using residential as a business space and production in Proto Batik Village. The results of this study found that the spatial management system in Proto Batik Village is dominated by women in every home. If the living room in business space used as a place to sell and marketing, the function of production room is located in women area such as kitchens, and backyard. It can be concluded that private house spaces are still used as residential functions, but semi-public spaces are utilized as production and business space.
\end{abstract}

Keywords : Space Production and Workshop; Gender; Space Management; Home Industry

\section{INTRODUCTION}

Home industry products in Indonesia increase rapidly from year to year. Many the products have already gone international and been accepted by the people all over world. Indonesia consisting of diverse cultures has distinctive characteristics for its territories, resulting in a variety of home industries. One of the world-renowed product is batik. Batik is a cultural heritage that must be preserved because it has high artistic values. In Indonesia, a famous batik producer is Pekalongan city. Some villages in Pekalongan have distinctive batik features, one of which is Proto village. In this village, batik has evolved through its home industries. Almost $70 \%$ women in the village can craft batik. And almost all the houses in Proto become places for the industries, whether for crafting batik, selling batik or transforming batik fabrics into clothing.

In Proto, people use their houses for production and commercial activities, whereas according to the Law No. 4/1992 house is a building that serves as a residence or dwelling and means for a family to grow up. Therefore, that is very interesting to be studied. Houses supposed to serve as residence have turned into production and commercial functions.

Changes of the spatial function use in houses according to [1] is a result of the interaction of residents with their houses. This is as it has been disclosed [2] where the human response to its environment depends on how the individual perceives its environment.

While according to [3], a good house planning includes the organization of its functions and spaces. So, houses need a good space organization to suit their functions. As the theory [4] in form planning, space and order also 
mentions that it is necessary to have relationships between elements to create a good space according to its function. Therefore, it is in contrast to the phenomena in Proto village of Pekalongan where the function of houses mixes with the production and commercial activities. Therefore, it is needed a research on the space organization of houses.

Similar research that has been conducted by [5] is about identification of batik productive house space and relation between spatial pattern of batik productive house by [6]. This study is aimed to uncover the meaning of the behavioral phenomena of human life: human kind in the capacity of individuals, groups and the wider community in using houses for commercial and production Batik spaces.

\section{METHODS}

Proto Village of Kedungwuni District is a village famous for its batik products. The village has many batik craftswomen actively maintaining their local culture. Many batik craftswomen have primary intention to preserve the local culture of Pekalongan. Yet among them are also founded those making batik for business or commercial purposes, even they become distributors of the batik fabrics to various cities. The surrounding created in this village is the environment closely related to the culture of batik crafting. So, Proto can be called as a batik village. This is in accordance with [8] who argued that settlements are the reflection of socio-cultural forces, the forms of neighborhoods are not the result of a simple process of causal factors, but rather a consequence of the overall socio-cultural factors. Batik village of Proto was formed because its people want to preserve the culture.

This study used a qualitative method of phenomenological paradigm, which attempts to understand the meaning (search for meaning) of events and their linkages with ordinary people in certain situations (J. Moleong, 2001). This study tried to uncover the meaning of the behavioral phenomena of human life, whether human kind in the capacity of individuals, groups, or the wider community in using residences for commercial and production spaces. Observation on the field, data mining was done through various ways: interviews, questionnaires and direct interaction with the actors in the commerce and production.

Meanwhile, scoring analysis is used to provide an assessment of the availability and service of infrastructure in each sub district that has slum areas in Banyumanik. Through these assessments then the analysis was used to determine the slum level in the study area.

\section{THEORITICAL REVIEW}

\section{Women as Managers of Batik Craft Home Industries}

Sparing their time to work at home is as a way for women to start a business. The women have much time for carrying out their house works while working. So, the household tasks management will not be neglected. Women's task is to manage household, but they can also use their spare time for working to increase their family income. Starting a business from home is also a significant savings because it can reduce the need for the cost of renting or buying a place for running business.

The household responsibilities for women are: Maintaining and managing the household - designing the interior, since location and physical structure of the house becomes an important aspect for women in the sense that the house is not meant solely to men in the household [9]. The women existence at homes has domination more on the household affairs. Business activities are not major barriers to carry out duties as a woman. The women existence at homes is more dominant than the men.

\section{Aspects That Affect a Residence}

The practices of dwelling in various communities have various patterns in accordance with the culture embraced by the community. According to [8], there are five aspects that influence the form of dwelling: (a) Some basic needs, (b) Family, (c) The Position of Women), (d) Privacy, (e) Social Intercourse. The position of women is appeared to have a role in influencing the form of residence. The existence of women at home dominates more on the household affairs. In the cases studied, the business activity is not a main barrier to perform the duties as a woman. As a result, the women who do not work can use their homes as places to increase their income. 


\section{Aspects of the Home Function Changing}

The aspect that is a benchmark in home changing based on theory [10] is related to the problem of space, including: the organization of space, the hierarchy of space, and the orientation of space. The existence of production and commercial space as a management space for gender will affect the pattern of space in a house. Physically, the changes can be the addition, reduction, shift and use of space in mix (mix use).

\section{RESULT AND DISCUSSION}

\section{The Layout of Production and Commercial Space of Houses}

Sample 1 (Mrs. Warsiti's House)
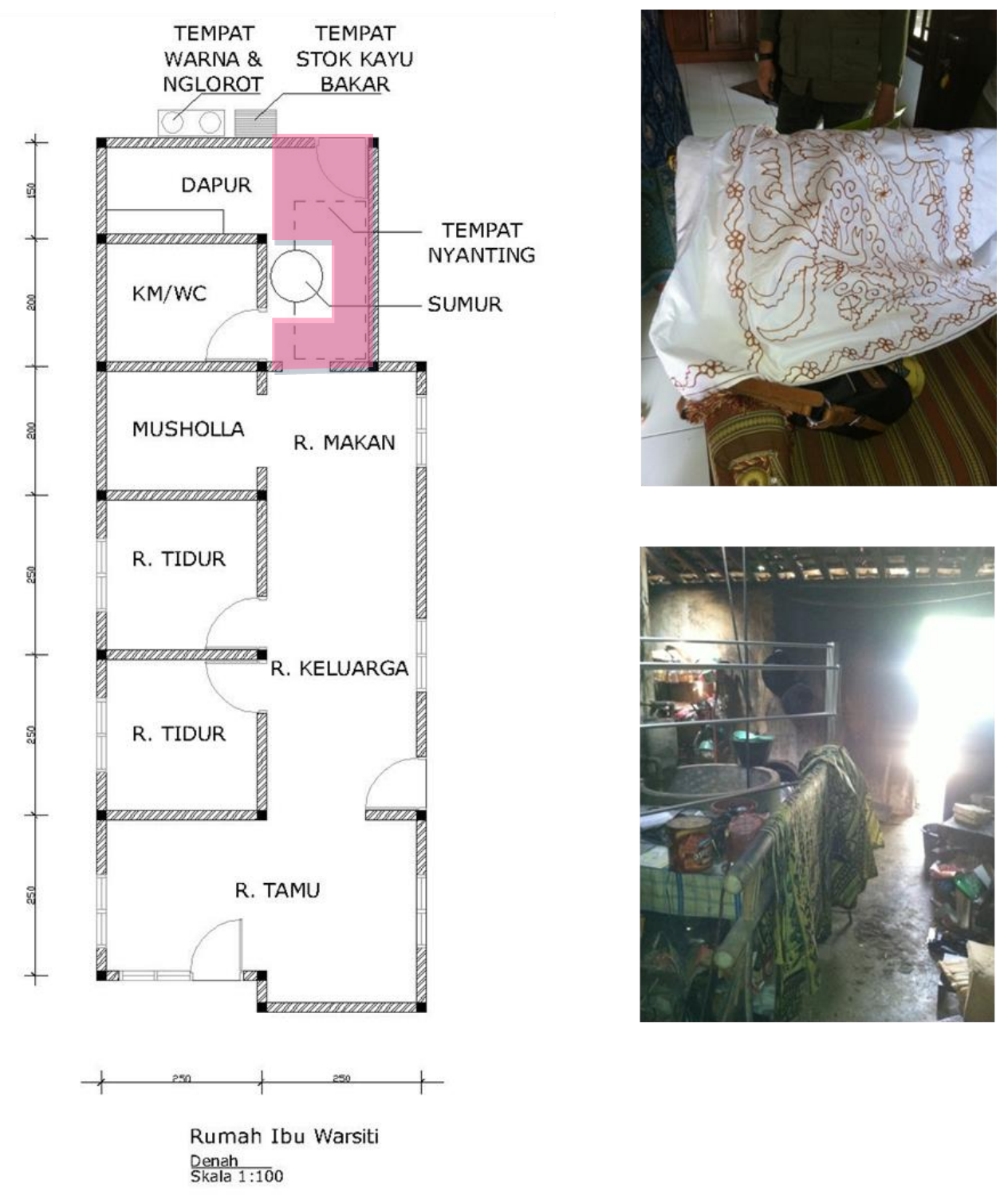

FIGURE 1. Floor Plan of Mrs. Warsiti's House

The house in Sample 1 is as a residence and production place. The homeowner uses the spaces around the kitchen and the bathroom to produce batik. The backyard also plays a role to support the activities of batik 
production. The mother is the main actor in this production activity. Therefore, the room in the back dominated by women becomes a space used for the production.

Sample 2 (Mrs. Siti Dariah's House)

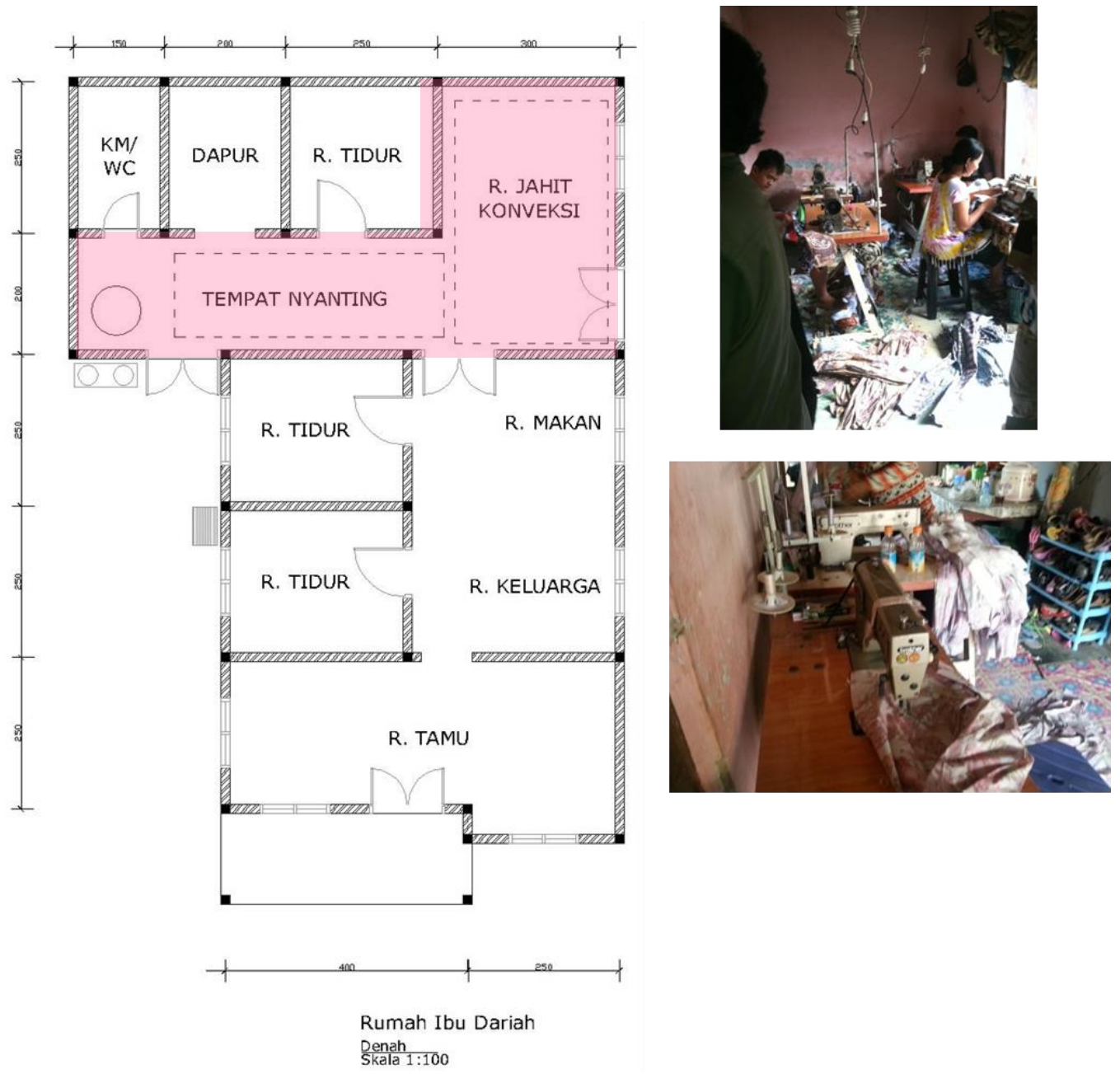

FIGURE 2. Floor Plan of Mrs. Siti Dariah's House

In the second sample, there was found production and commerce activities. The home is served as a place of batik production and sewing room/convection. There are two kinds of production in this house, while the living room is used for marketing their products (store). In this house, the mother acts as the craftswoman, while her daughters carry out a convection business. Therefore, the spaces used are still the rooms related to women located on the back near the kitchen. 

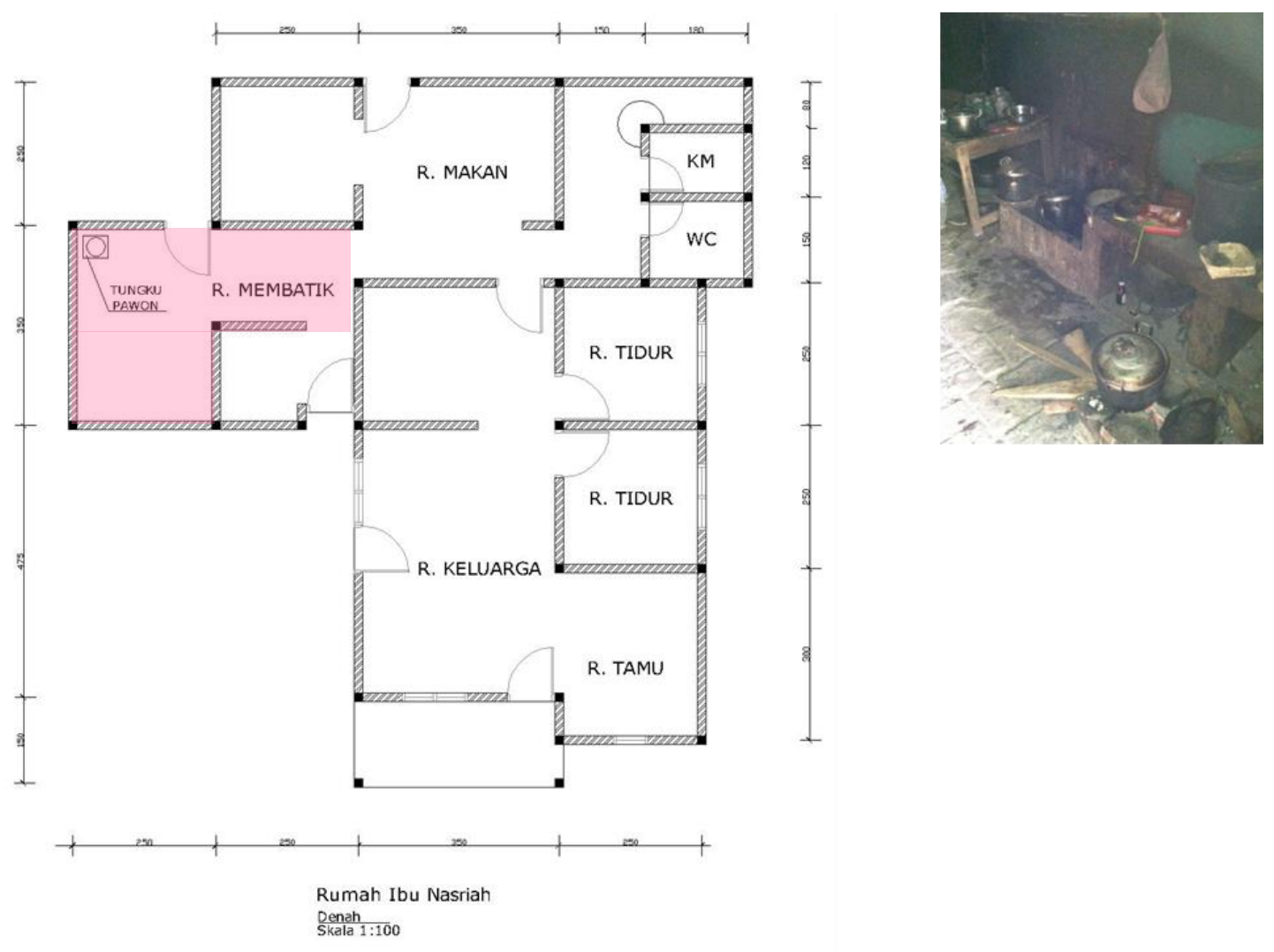

FIGURE 3. Floor Plan of Mrs. Siti Nasriah's House

At the third sample, the house is used for batik production only. Like the other samples, the main actor of the production at the home is the woman. Therefore, the spaces used are those related to woman's tasks. In this case, they are close to the kitchen and the backyard, area for drying clothes. 


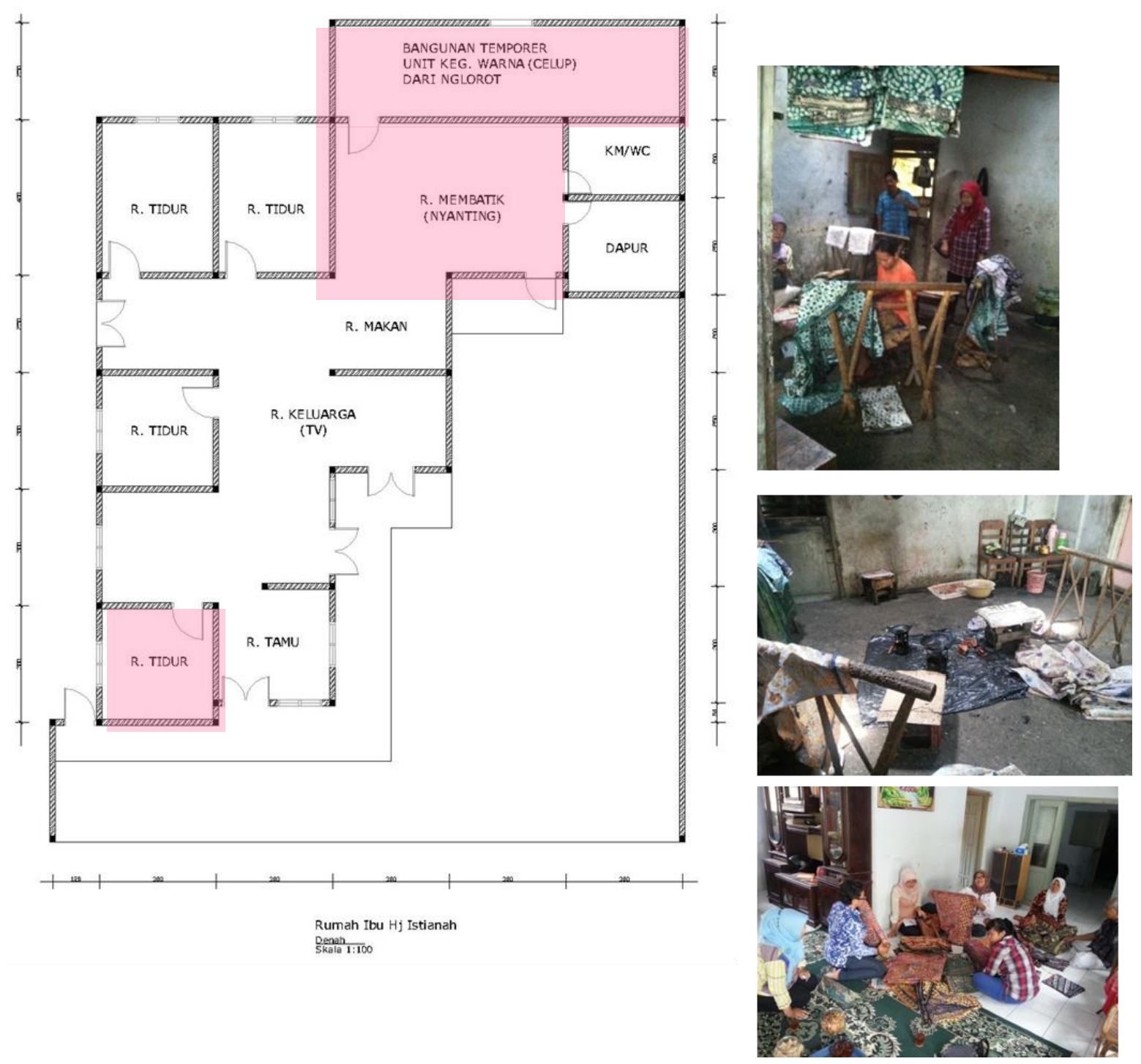

FIGURE 4. Floor Plan of Mrs. Hj. Istianah's House

The fourth sample is a large home production, as a mass production which employs neighboring women who do not work producing batik in their houses. But there is no specific place as well. It is just space in the back which are close to the kitchen and backyard. While, the front of the living room is used for the space for selling and buying the products. 

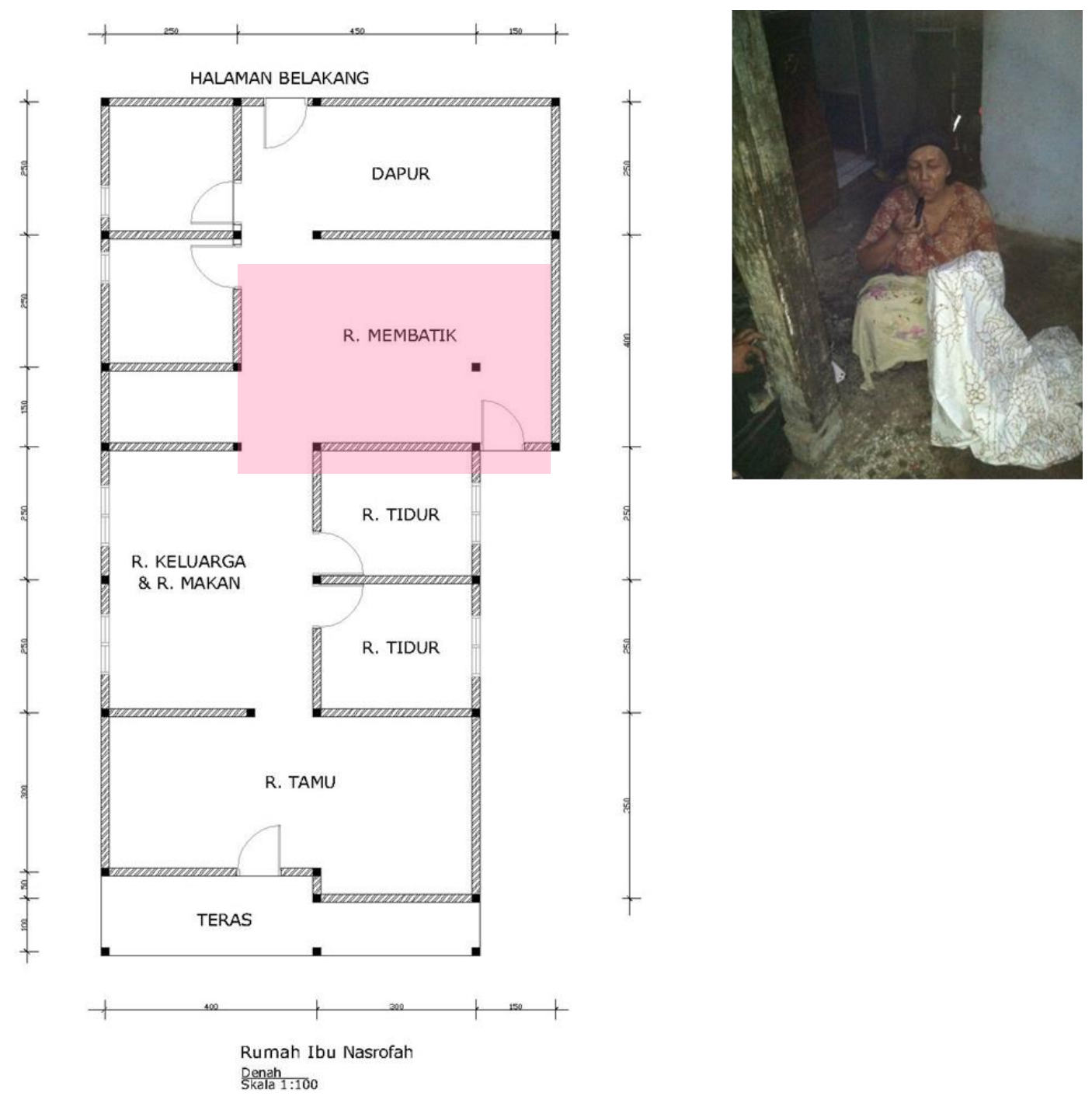

FIGURE 5. Floor Plan of Mrs. Nasrofah's House

The home of sample 5 produces batik for generations. Hence, in the house, there is already special space for batik production. The location is also in the area of women's power, which is close to the kitchen.

Management of House Function as production and Commercial Space According Rappoport (1969) there are five aspects that influence the form of dwelling.

1. Some Basic Needs

The phenomena found in the field showed that batik maker's house in Proto is a basic need for the inhabitants. That basic need includes the concept of home, which is to protect from the heat and rain, comfortable, and to have spaces in accordance with the needs of its inhabitants. Batik makers' houses in Proto already fulfill those elements. Consequently, technically the home as a basic need is met. Having fulfilled it, so the houses have evolved according to the batik makers' needs, such as the expansion of the service room because it is used as an area to make batik. The home yard will be retained broad to accommodate batik making activities. Those are what distinguish batik makers' house with houses in general. 


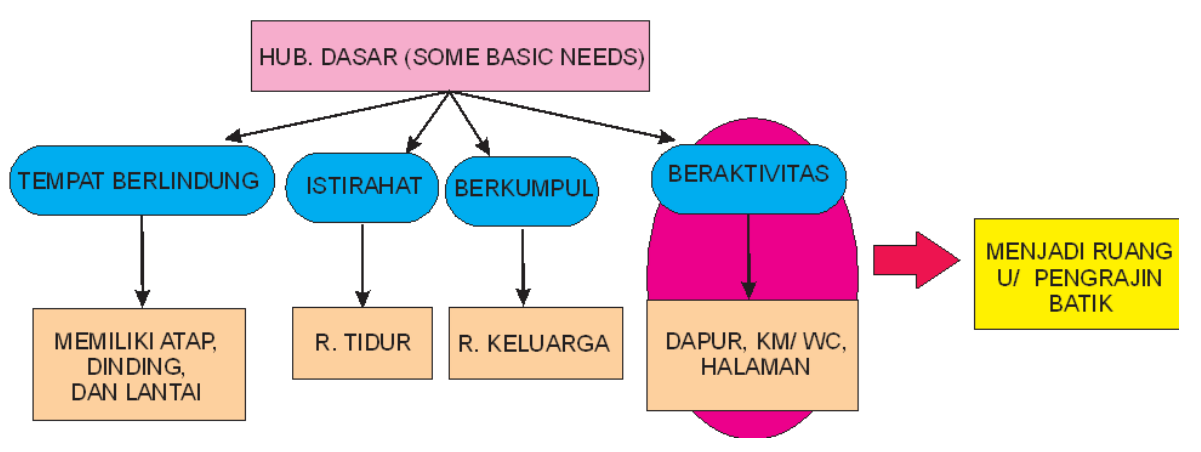

FIGURE 6. Basic Needs fromThe Inhabit Batik Makers' Houses

2. Family

The families of batik craftswomen in Proto Pekalongan do not mind with the crafting activities done by one of the member. Designing batik is considered something that must be performed to preserve the local culture. Moreover, the skill of writing (crafting) batik has been taught to all their offspring, but today many are not interested in the designing. Yet, it grows into a convection that is still associated with batik. As what happen in Mrs. Siti's house, her children develop a batik convection, while she is remained with designing batik. As a result, their workspace is divided into two. The activity of designing batik that is only performed by herself is located in an area near the well and the side yard, while the convection is located near the kitchen, and the living room is turned into a warehouse to keep temporarily the convection products that will be marketed.

3. The Position of Women

Woman is a minister in a household. Therefore, it is no doubt of her role in the household. The main activities of household are held by a woman. Such as what encountered in Proto village, women individually perform their duties as a mother to her children, a wife for her husband and an employer for herself. It can be seen from the activities carried out: cooking, washing, drying, cleaning her house which are still performed by a craftswoman in Proto. Meanwhile, after all these activities are finished, the women turned into batik craftswomen as their side job or main job. Thus their spaces for crafting batik are the spaces in which the women usually do their activities, like in the kitchen, near the well, in the bathroom and the home yard.

4. Privacy

The house zoning is usually made based on the needs and behavior of the occupants. At the batik craftswomen's house in Pekalongan, the service room zone becomes private room for women. So, there they feel comfortable to do batik crafting and their household activities.

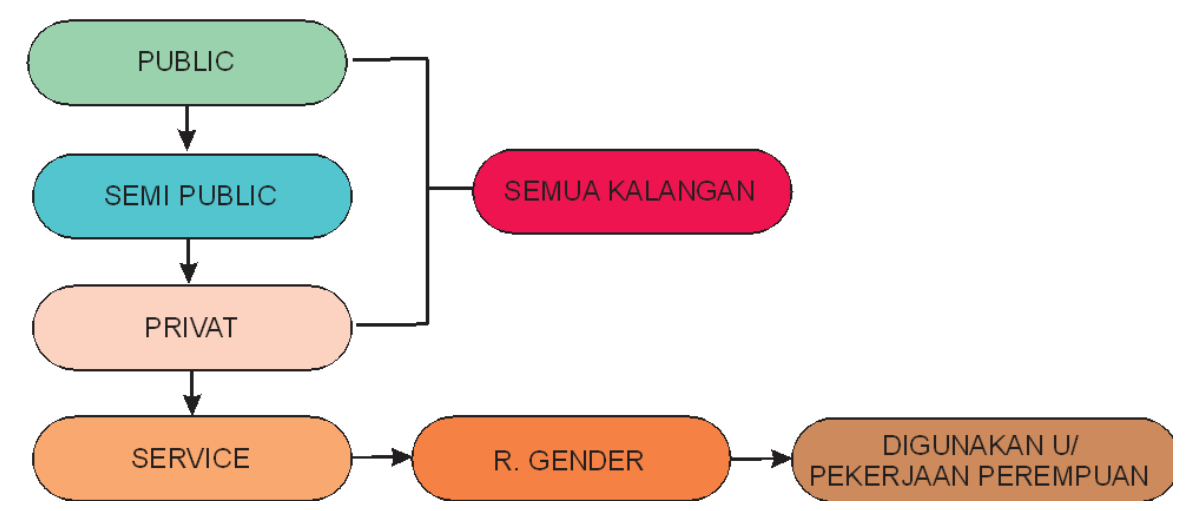

FIGURE 7. The House Zoning of Batik Makers' Houses

From the analysis results and questionnaires distributed in Proto, it is showed that the use of the residence spaces as the production function: public spaces $0 \%$, private space $0 \%$, and service room $100 \%$. In other words, all of the batik makers in Proto use service rooms as the spaces to produce batik. Production space in residences: 
Reasons for using the service room are:

- The activity requires water, so it uses the space close to the water source

- $\quad$ The activity needs light

- Batik-making process results in waste

- Preventing to use the other spaces as not to contaminate them.

5. Social Relation

The batik craftswoman in Proto village does not only do crafting activities in her home alone. As in Mrs. Hj. Istianah's house, the neighboring women are also asked to be craftswomen in her house. Yet, the activity is just during the afternoon because in the morning the women still perform their tasks respectively as mothers in their house. Meanwhile, in the evening they have to take care of their children and husband. So, the activity of batik crafting is carried out in the afternoon only. Therefore, not only is in the Proto environment formed gender-based spaces, but also formed a gender-based time. The social relation among the women in Proto is very close to each other.

\section{CONCLUSION}

It can be concluded that all activities in batik production and commerce in the Proto Pekalongan are influenced by the women's role as the main actors. The spaces used for the production are the service spaces close to the women's power. While the commercial spaces are always in the living rooms as they are public spaces located in the front of the house which are easily accessible.

Of the phenomena that occurred in the field, it is concluded that the women are the primary actors of the production and commercial activities in Proto. They have special spaces that become their power area to make batik, but still have to work as a woman individually. The spaces are the service area and the spaces that are close the bathrooms, the wells, the kitchen, the backyard, and the side yard. Therefore, the gender spaces in the house of batik maker are spaces in the service area.

The commercial space is always in the living room, which is located in public space since it may be visited by everyone. The commercial space is a place that must be easily accessed. Everyone can go in and visible when people pass by. Therefore, the living rooms as public spaces in residences are used as commercial places. The existence of the space does not disturb the function of house as a residence, because the function of living room only exists when guests come along.

\section{ACKNOWLEDGMENTS}

The author would like to acknowledge the Institute for Research and Community Service of Diponegoro University for support of the research project. And also wishes to thank the community of Proto Batik village that have been supporting research data.

\section{REFERENCES}

[1] J. Silas, Rumah Produktif, Dalam Dimensi Tradisional Dan Pemberdayaan. Surabaya: UPT ITS, 2000.

[2] S. Triatmodjo, "Evaluasi Pasca Huni Aspek Perilaku di Kecamatan Mantrijeron Kota Yogyakarta," Lintas Ruang, vol. 2, no. 2, 2008.

[3] H. Frick, Membangun dan Menghuni Rumah di Lerengan. Yogyakarta: Kanisius, 2003.

[4] F. D. K. Ching, Arsitektur: Bentuk, Ruang Dan Susunannya. Jakarta: Erlangga, 2000.

[5] R. R. Kridarso, E.R. \& Tobing, "Identifikasi Pola Tata Ruang Rumah Produktif Batik Di Lasem, Jawa Tengah," in Seminar Nasional Riset dan Teknologi Terapan (RITEKTRA), 2017.

[6] E. R. Kridarso, "Relasi Antara Pola Tata Ruang Rumah Produktif Batik dengan Karakter Etnisitas Penghuni di Kota Pekalongan, Jawa Tengah,” Universitas Katolik Parahyangan, 2017.

[7] M. L. J., Metodologi Penelitian Kualitatif. Bandung: Remaja Roskakarya, 2000.

[8] A. Rapoport, House Form and Culture. Prentice Hall: Englewood Cliffs, N.J, 1969.

[9] T. W. Murtini, "Makna Ruang Gender Pada Rumah Tinggal Di Kampung Kauman Semarang," Universitas Diponegoro, 2010.

[10] N. J. Harbraken, The Systematic Design of Support. Cambridge: Massachusset: Laboratory of Arch and Planning MIT, 1978.

Undang-undang nomor 4 Tahun 1992 